\title{
Syariah Branding; Komodifikasi Agama Dalam Bisnis Waralaba di Era Revolusi Industri 4.0
}

\author{
Hasan Baharun, Harisatun Niswa \\ Universitas Nurul Jadid, Paiton, Indonesia \\ ba54nbaharun@gmail.com,niswaharisatun@gmail.com
}

\begin{abstract}
This paper presents the phenomenon that develops in society, related to the existence of religious commodification in business, namely the labeling of "Syari'ab" as a medium to attract customer loyalty in the era of industrial revolution 4.0. The labeling of "Syari'ab" is used as a strategy by industry players by utilizing religion as a selling value to get attention from consumers. Religion is exploited, explored and used as a commodity by the community to take advantage. Kopotren Basmalah as the research site is present as one of the real applications of the pesantren Sidogiri which wants to become a boarding school capable of competing in the world of economy. Pesantren Sidogiri modifies the science of religion and economics to give birth to a sharia-based retail company. A phenomenon that develops in this business, religion is used as a media or tool to sell products from the business. This study uses a qualitative method with phenomenology. The results show that the public perception of the branding of "syari'ah" conducted by the Basmalah copontren namely; loyal oriented customer, performing image, santri entrepreneurship, a place for social piety and debating beliefs in the business of buying and selling.
\end{abstract}

Keywords: Syariah Branding, Islamic Business, Industrial Revolution 4.0.

\begin{abstract}
Abstrak
Tulisan ini mengkaji tentang fenomena yang berkembang di masyarakat, terkait dengan adanya komodifiksi agama dalam dunia bisnis, yaitu labelisasi "Syari'ab" sebagai media untuk menarik loyality costumer di era revolusi industri 4.O. Labelilsasi "Syari'ab" dijadikan sebagai strategi oleh pelaku industri dengan memanfaatkan agama sebagai nilai jual untuk memperoleh perhatian dari konsumen. Agama dieksploitasi, dieksplorasi dan dijadikan sebagai komoditi oleh masyarakat untuk mengambil keuntungan. Kopotren Basmalah sebagai situs penelitian ini hadir sebagai salah satu aplikasi nyata dari Pesantren Sidogiri yang ingin menjudge sebuah pesantren mampu bersaing dalam dunia perekonomian. Pesantren Sidogiri memodifikasi ilmu agama dan ilmu ekonomi untuk melahirkan sebuah perusahaan ritel yang beratasnamakan syariah. Fenomena yang berkembang dalam bisnis ini, agama dijadikan wahana atau media atau alat untuk menjual produk dari bisnis tersebut. Penelitian ini menggunakan metode kualitatif jenis fenomenologi. Hasil penelitian menunjukkan bahwa, persepsi masyarakatterhadap branding "syari'ab" yang dilakukanoleh kopontren Basmalah sebagai bagian dari komodifikasi agama menunjukkan persepsi yang bervarariasi, yaitu; customer loyality oriented, performing image, santri entrepreneurship, ajang kesalehan sosial dan perdebatan keyakinan dan jual beli.
\end{abstract}

Kata Kunci: Branding Syariah, Bisnis Islam, Revolusi Industri 4.0

Permalink/DOI: http://dx.doi.org/10.18326/infsl3.v13i1.75-98 


\section{Pendahuluan}

Perkembangan dunia perekonomian pada abad ke-20 bergerak sangat cepat dan dinamis, hal tersebut disebabkan oleh kemajuan teknologi informasi yang semakin pesat. Kemajuan ini oleh para ahli ilmu sosial disebut era disrupsi. Era disrupsi merupakan era transformasi digital di mana seluruh sektor merasakan dampaknya, baik sektor politik, pertanian, pendidikan maupun ekonomi (Harto, 2018 : 1)

Menurut Renald Kasali dalam jurnalnya Kasinyo Hartono, era disrupsi itu merupakan masa yang mengancam dan mempunyai tantangan berat pada kehidupan manusia di mana orang-orang yang tidak mampu untuk beradaptasi dengan perubahan, tentu akan mengalami banyak kesulitan dalam mengarungi gelombang kehidupan sehari-hari yang penuh akan sebuah perubahan dan persaingan (Harto, $2018: 2$ ).

Selain era disrupsi, yang sedang gencar-gencarnya berkembang di Indonesia, dalam sektor industri berkembang sebuah revolusi industri di mana revolusi industri tersebut terjadi pada masa ke 4 . Industri 4.0 adalah suatu kesatuan dari Cyber Physical System (CPS) dan Internet of Things and Services (IoT dan IoS) pada proses industri yaitu logistik, manufaktur serta proses industri lainnya di mana CPS adalah teknologi untuk mengsignifikan antara dunia nyata dengan dunia maya (Prasetyo \& Sutopo, $2018: 19$ ).

Era revolusi industri 4.0 ini berkembang dengan sangat cepat, di mana semua sistem mulai terhubung dengan era digital. Era industri ini berkembang melalui konektivitas dan digitalisasinya sertamampu menaikkan efsiensi manufaktur dan kualitas produk. Namun disisi lain, revolusi industri 4.0 memberikan dampak negatif, yaitu akan menghilangkan 800 juta lapangan kerja di seluruh dunia hingga tahun 2030, karena diambil alih oleh tenaga robot. Hal ini dapat menjadi hambatan untuk Indonesia sebagai negara berkembang yang mempunyai tenaga kerja serta angka pengangguran yang cukup tinggi (Satya, $2018: 19$ ).

Transformasi digital dipandang perlu untuk kemajuan dunia perekonomian di Indonesia. Dewasa ini, perekonomian 
di Indonesia diramaikan dengan semarak sistem ekonomi Islam. Sistem ekonomi Islam hadir ditengah era industrialisasi untuk menjadi solusi dari sistem ekonomi kapitalis dan sistem ekonomi sosialis yang dianggap sudah mulai menurun. Sistem ekonomi Islam merupakan sistem yang berjalan sesuai dengan ajaran Islam, mengacu kepada Al-Qur'an dan Hadis yang akan membawa keadilan dan kesejahteraan bukan hanya kepada umat Islam namun juga seluruh umat manusia, karena Islam adalah rahmat bagi seluruh alam (Muslim, $2012: 309$ ).

Ekonomi Islam merupakan penggabungan antara dua kata ekonomi dan Islam. Ekonomi adalah ilmu yang mempelajari tentang integrasi dari kegiatan produksi, konsumsi serta distribusi (Ghufron, 2017 : 24). Sedangkan Islam merupakan salah satu jenis agama yang berkembang di dunia. Agama Islam lahir dimuka bumi untuk menyempurnakan akhlak manusia. Agama Islam hadir untuk menjawab tantangan zaman yang penuh akan siksaan dan derita pada zaman Jahiliyah. Islam menjadi rasa penghilang rasa dahaga dan obat mujarab untuk menyongsong kehidupan selanjutnya.

Sebagai bagian dari dinamika perkembangan ekonomi Islam, banyak penelitian tentang ekonomi yang dikaitkan dengan agama sehingga menarik untuk dikaji. Zanurrosyid yang melakukan penelitian tentang komodifikasi agama dalam Islamic Tourism dan aktivitas ekonomi. Hasil penelitiannya menunjukkan bahwa, di kompleks makam Syekh Ahmad Mutakkin yang berkediaman di Kabupaten Pati, Provinsi Jawa Tengah terdapat aktivitas ekonomi, yaitu munculnya pedagang yang menawarkan aneka jenis makanan, minuman, hiasan, serta pakaian untuk penziarah makam. Hal tersebut merupakan suatu komodifikasi agama yang dilaksanakan oleh masyarakat sekitar, dikarenakan agama dijadikan alat untuk memperoleh keuntungan sebagai pemuas kebutuhan duniawi. Lapangan pekerjaan tersedia dari barakahnya makam Syekh Ahmad Mutakkin, hal tersebut dimanfaatkan oleh masyarakat dengan berdagang berbagai jenis sandang pangan dan terjadi transaksi tawar menawar untuk menyepakati harga yang dilakukan oleh pedagang dan penziarah makam. Bagi pemerintah desa, hal tersebut mampu meningkatkan perekonomian desa melalui uang sewa lahan parkir untuk penziarah (Zaenurrosyid \& Ulfiana, 2016 : 121). 
Selaras dengan itu, Asmaul Husna juga mengkaji tentang komodifikasi Agama: pergeseran praktik bisnis dan kemunculan kelas menengah muslim. Hasil penelitiannya menunjukkan bahwa; kemunculan kelas menengah muslim dikarenakan banyaknya produk-produk yang mengatas namakan Islam. Produk dengan label halal pada kemasan menjadi ajang perdagangan agama. Agama merupakan sesuatu yang sakral bergeser menjadi alat untuk memperlaris barang dagangannya. Komunitas baru yaitu kelas menengah muslim yang melabelkan dirinya taat beragama akan menguasai pasar. Komunitas baru tersebut merupakan asumsi konsumen sendiri yang melabelkan dirinya (Husna, 2018 : 237).

Begitu juga dengan penelitian yang dilakukan oleh Yulfan Arif Nurohman tentang Theoritical Review: Teori Merek Halal. Peneliti memfokuskan kajiannya pada pemasaran serta branding Islam. Halhal yang mencakup kategori utama indutri halal adalah makanan, gaya hidup, dan layanan. Sedangkan untuk mendistribusikan barang dari produsen ke konsumen hendaknya melalui lima pilar, yaitu : konsumen muslim yang akan mengkonsumsi dan menggunakan merek-merek Islam, pendidikan dan penelitian yang mampu menjadikan merek halal sebagai objek untuk diteliti sehingga mampu melaksanakan pelatihan tentang model tersebut. Jaringan integrasi halal yang dipelopori oleh kelompok-kelompok tertentu seperti bandara, pelabuhan, gudang, dan terminal yang berkaidah halal sehingga mampu menjadi gerbang halal bagi pendistribusian merek-merek halal, rantai pasokan halal adalah hubungan produsen, konsumen dan distribusi yang berkomitmen untuk menerapkan prinsip syariah yang mampu memainkan jalur barang dengan baik, dan pelaku konsumen yang memegang peran penting untuk penyaluran merek halal adalah pemerintah, keuangan syariah dan perdagangan halal mampu mendukung dan memberikan support kepada merek halal untuk mempermudah jalaur distribusi, selain itu memberikan peraturan-peraturan yang membantu berjalannya merek halal (Nurohman, 2017 : 86).

Dari berbagai penelitian di atas, peneliti tertarik untuk mengkaji tentang fenomena yang berkembang di masyarakat, terkait dengan adanya komodifiksi agama dalam dunia bisnis, yaitu dengan adanya labelisasi "Syari'ah" sebagai media untuk 
menarik loyality costumer di era revolusi industri 4.0. Labelilsasi "Syari'ah" dijadikan sebagai strategi oleh pelaku industri dengan memanfaatkan agama sebagai nilai jual untuk memperoleh perhatian dari konsumen agama dieksploitasi dan dieksplorasi oleh kaum kapitalis untuk mengambil keuntungan.

Hal inilah yang menjadi keunikan penelitian ini, mengingat maraknya labelisasi "Syari'ah" yang dijadikan media untuk mensukseskan bisnis yang dilakukan oleh kelompok atau organisasi tertentu. Penelitian ini terfokus pada persepsi masyarakat di Kabupaten Probolinggo terhadap keberadaan Kopotren Basmalah Sidogiri.

\section{Komodifikasi Agama : Konsumerisme Spiritual}

Komodifikasi diserap dari bahasa inggris yaitu "commodification" yang berasal dari kata "Commodity" yang memiliki arti sesuatu yang diproduksi untuk dijual. Komodifikasi merupakan gabungan dari dua kata yaitu komoditas dan modifikasi. Komoditas adalah benda perniagaan utama dan modifikasi adalah transformasi varian bentuk dan ukuran ke bentuk dan ukuran yang baru. Secara praktis, komodifikasi adalah proses perubahan dari nilai-nilai kehidupan menjadi sebuah nilai yang bisa dipasarkan.

MenurutVincent Moscoyangdikutip dalamjurnal Muhammad Fakhrudin Yusuf mengungkapkan bahwa komodifikasi adalah the process of transforming use values into exchange values atau proses perubahan suatu nilaiguna menjadi nilai tukar dimana ada harga yang ditetapkan oleh seorang produsen (Yusuf, 2016 : 31). berikut:

Terdapat tiga pembagian bentuk komodifikasi yaitu sebagai

a. Komodifikasi konten, merupakan transformasi pesan yang hanya berupa data menjadi sebuah pemikiran yang berbentuk produk yang siap untuk dipasarkan dan dinikmati oleh konsumen.

b. Komodifikasi audiens, merupakan pelelangan audiens yang siap untuk dijual demi kepentingan tertentu kepada pengiklan. 
Audiens dijadikan komoditi untuk dapat meramaikan dunia periklanan. Media membuat rating yang tinggi untuk dijual kepada pengiklan dengan memanfaatkan jam tayang. Caranya adalah dengan membuat dan merancang program yang mampu memperoleh rating tertinggi dibandingkan dengan stasion sebelahnya.

c. Komodifikasi pekerja, merupakan komoditas jam kerja pekerja yang memiliki keahlian tertentu dihargai dengan upah. Proses komodifikasi pekerja memiliki keterkaitan dengan produk yang dihasilkan, sedangkan proses produksi erat kaitannya dengan fungsi atau guna pekerjaannya, pekerja telah menjadi komoditas dan telah dikomodifikasikan oleh pemilik modal, yaitu dengan cara mengeskploitasi pekerja dalam pekerjaannya dengan menambah jam kerja (Susanti \& Rochman, 2016 : 205).

Komodifikasi erat kaitannya dengan kapitalis. Kapitalisme adalah sistem yang berorientasi pada uang atau "money oriented". Sistem ini memberikan peluang besar kepada pemilik modal untuk mengeksploitasi kekayaan. Para pengusaha akan berlombalomba untuk menumpuk modal dengan menghalalkan segala cara. Kapitalisme memicu kegiatan komersial untuk memperoleh keuntungan materiil.

Sedangkan agama merupakan kepercayaan, keyakinan serta pola tingkah laku, yang diyakini oleh manusia untuk memecahkan masalah-masalah rumit dan kompleks yang tidak mampu dilogikakan dengan akal, tidak mampu diselesaikan dengan suatu organisasi, dan tidak mampu dipecahkan oleh teknologi yang handal (Marzali, 2012 : 59). Agama merupakan sumber nilai dari segala nilai yang sudah mendarah daging dan menjadi ketentuan atau pedoman hidup untuk penganutnya. Agama dipahami sebagai teori atau doktrin yang tercantum dalam kitab suci masing-masing, namun perlu dikaji dari kacamata sosial, ekonomi, historis dan politik.

Agama adalah sebuah doktrin yang membawa kemaslahatan kepada pemeluknya didunia maupun diakhirat karena menyeru kepada umatnya untuk hidup berdampingan secara damai serta membuat hati menjadi tentram (Hidayat, Sujana, \& Al Gadri, 
2018 : 109). Agama merupakan pedoman hidup yang ditetapkan oleh Tuhan yang mengatur tata cara ibadah manusia terhadap tuhannya, yang wajib dilaksanakan sesuai syariah yang ditetapkan (Toha, 2014: 2).

Dari masing-masing pengertian di atas, dapat dipahami bahwa komodifikasi agama merupakan proses yang diciptakan pada jalur ekonomi dan agama. Komodifikasi bukanlah suatu aliran baru yang bertentangan dengan praktik dan keyakinan agama sebelumnya, akan tetapi lebih mengarah kepada cara berpikir tentang agama sebagai suatu komoditi berfungsi religius mampu dikonsumsi dengan layak oleh konsumen.

Secara praktis, komidifikasi agama ialah penyaluran nilai-nilai spiritual yang berkeyakinan kepada Tuhan dan menjadi pedoman hidup menjadi nilai tukar. Proses komodifikasi agama berjalan lancar melalui kebebasan setiap individu untuk menentukan hak dan kewajiban dalam beragama. Agama dijadikan sebuah produk yang bisa diperjualbelikan dan dinikmati oleh khalayak ramai. Agama merupakan rakitan berangka semata yang dijadikan alat untuk memenuhi kepuasan kapitalis. Agama dimodifikasi sesuai permintaan pasar yang standar yang sudah ditentukan oleh produsen (Zaenurrosyid \& Ulfiana, 2016 : 110).

Komodifikasi agamadimaknai sebagai strategi yang dilakukan oleh pelaku industri dengan memanfaatkan agama sebagai nilai jual untuk memperoleh perhatian dari konsumen. Pelaku industri berlomba-lomba untuk memperoleh label syariah atau halal dari suatu produk yang dihasilkan untuk mampu bersaing dengan kompetitornya (Husna, $2018: 229$ ).

Berangkat dari hal tersebut, dapat dipahami bahwa agama menjadi sesuatu yangdikonsumsi oleh masyarakat, namun dalam hal ini bukan agama sebagai realitasobjektif, akan tetapi sebagai simbol (Fakhruroji, 2016 : 10). Hal ini dapat dipahami bahwa, yangdikonsumsi dalam aktivitas ekonomi bukanlah esensi agama itu sendiri, akan tetapi citra agama sebagai simbol keagamaan yang mulai dimanfaatkan oleh masyarakat sebagai labeling tertentu. 


\section{Branding Syariab: Popularitas Agama}

Brand adalah sebuah simbol dan nama yang dimanfaatkan oleh seorang penjual untuk mengidentifikasi produk yang dihasilkan yang mampu membedakan dengan produk lain yang serupa tapi tak sama, selain itu brand berfungsi sebagai tanda pengenal akan sebuah produk tertentu (Roziqin \& Rozaq, 2018 : 231).

Kata branding muncul akibat persaingan dunia bisnis yang semakin pesat, tajam dan penuh persaingan yang semakin ketat, sehingga perusahaan harus mampu memproduksi sebuah produk yang memiliki ciri khusus atau tanda pengenal untuk mampu membedakannya dengan produk lain. Penguatan peran label merupakan salah satu strategi yang mampu diterapkan oeh seorang pebisnis untuk mempertahankan perusahaannya.

Branding merupakan cara untuk membangun pernyataan rasional, emosional kultural dari suatu merek (Farid, 2017 : 60). Brand adalah suatu yang berupa nama, slogan, logo, dan simbolsimbol lain yang membedakan antara layanan dan produk dari kompetitor dengan kriteria-kriteria yang berbeda didalamnya. Selain itu, merek merupakan sesuatu yang dibentuk dibenak pelanggan yang memiliki kekuatan untuk membentuk kepercayaan seorang pelanggan (Roziqin \& Rozaq, 2018 : 232).

Branding yang dilakukan oleh organisasi atau komunitas menjadi suatu keniscayaan dalam aktivitas pemasaran di dunia bisnis (Farid, 2017 : 60). Branding syariah merupakan tanda pengenal yang sesuai dengan ketentuan syariah dan berlandaskan iman serta semua kegiatan yang dilaksanakan harus bersifat lillahi ta'ala.

Dalam ajaran Islam ada situasi yang harus tegasdan jelas dipatuhi oleh semua perusahaan bisnis untuk mendapatkan izin pengoperasional penggunaan nama-nama yang berbau Islami. Dalam Islam, merek atau brand yag tidak sesuai dengan ketentuan syariahharus memenuhi kriteria yang berkaitan dengan bahan baku dan proses produksi. Keberhasilan sebuah produk yang memenuhi kriteria tertentu boleh menggunakan nama-nama Islami 
secara komersial. Sehingga, agama memiliki peran urgen dan aktif dalam memainkan peran transformasi bisnis menjadi sebuah entitas etis yang bertujuan untuk meningkatkan pendapatan dan laju penjualan (Nurohman, 2017 : 90).

Branding syariah dapat diartikan sebagai penggunaan nama-nama yang berkaitan dengan Islam disebuah perusahaan bisnis atau menunjukkan identitas halal untuk sebuah produk. Seperti contoh: rumah sakit syariah, hotel syariah, wisata syariah, dan sebagainya. Branding Syariah dikategorikan kedalam tiga bentuk, yaitu a. Islamic brand by complience Islamic brand harus mampu menampilkan dan mempunyai unsur daya tarik yang kuat kepada konsumen dengan cara patuh serta taat kepada kaidah syariah Islam. Brand yang dikategorikan produk ini memiliki ciriciri sebagai berikut hasil produk halal atau yang berlabel syariah, diproduksi serta dikelola oleh negara atau perusahaan Islam, dan difokuskan untuk konsumen yang beragama muslim. b. Islamic brand by origin adalah pengaplikasian suatu brand kepada produk tanpa harus mencantumkan label halal dikemasan tersebut dikarenakan perusahaan atau negara tersebut sudah menganut agama Islam. c. Islamic brand by customer Branding adalah suatu cara atau langakah menerapkan label halal atau syariah pada suatu produk dikarenakan kegiatan produksi tidak dilaksanakan di negara muslim (Nasrullah, 2015 : 82).

\section{Bisnis Waralaba Perspektif Islam}

Bisnis merupakan kegiatan yang dilaksanakan oleh manusia untuk mendapatkan penghasilan dan memenuhi kebutuhan hidupnya dengan cara memanfaatkan, mengelola sumber daya manusia dan alam secara efisien dan efektif. Bisnis merupakan suatu organisasi yang mampu menjalankan aktivitas atau kegiatan memproduksi suatu barang, mendistribusikan barang serta jasa yang dibutuhkan dan diinginkan oleh konsumen untuk mendapatkan sebuah keuntungan (Zaroni, 1992 : 76). Dalam Al-Qur'an kata bisnis yaitu al-tijarah yang mempunyai makna berniaga atau berdagang.Allah swt. sangat menganjurkan untuk umatnya untuk berdagang (Susanti, $2016: 5$ ). 
Begitu juga Allah mendefinisikan bisnis didalam QS. Al A'raaf ayat 10 :

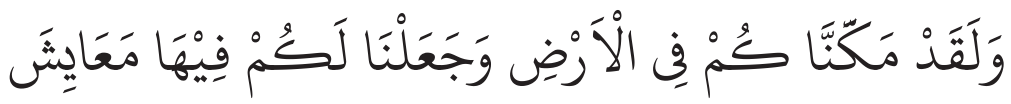

"Sesunggubnya kami telab menempatkan kamu sekalian di bumi dan kami adakan bagimu di muka bumi itu (sumbersumber) penghidup."

Tujuan dari kegiatan bisnis adalah laba. Konsep bisnis yang ditawarkan dalam ilmu ekonomi adalah produsen mampu memaksimalkan produksi yang dilakukan dengan biaya seminimal mungkin dan menghasilkan produk yang banyak dan berkualitas bagus. Kombinasi dari bahan baku atau sumber daya alam, tenaga kerja manusia, modal, manejemen dan mesin harus direncanakan sesuai dengan kebijakan perusahaan. Dalam bidang distribusi, pelayanan optimal yang dilaksanakan oleh perusahaan harus mampu memberikan kesan yang baik dimata konsumen, sehingga konsumen akan memberikan kepercayaan kepada konsumen (Astuti, 2005 : 84).

Menurut Pasal 1 No1 Peraturan pemerintah RI No 42 tahun 2007 tentang konsep waralaba diungkapkan bahwa : Waralaba adalah hak legislatif yang dimiliki oleh perusahaan atau unit usaha untuk memasarkan barang atau jasa yang telah terbukti berhasil sehingga mampu dimanfaatkan oleh pihak lain dengan kesepakatan waralaba (Rusli, 2015 : 10).

Jenis-jenis Waralabadibagi menjadi tiga kategori, yaitu;

1. Waralaba Merek dan Produk Dagang (Product and Trade Franchise) merupakan pemberian penggunaan nama merek dagang kepada penerima waralaba oleh pemberi waralaba dengan memperoleh suatu bayaran royalti dimuka dan mendapat keuntugan dari penjualan produk, contohnya; SPBU dengan merek Pertamina.

2. Waralaba Format Bisnis (Business Format Franchise) merupakan pemberian lisensi tentang keseluruhan paket, yang terdiri dari seluruh elemen perusahaan untuk mendapatkan skill terampil 
dalam bisnis yang dijalankan dengan ketentuan-ketentuan yang disepakati sebelumnya, seperti; AlfaMart, IndoMart. Proses bantuan yang diberikan kepada penerima waralaba yaitu, sebagai berikut :

a. Sistem operasional bisnis

b. Pengawasan, untuk memberikan perhatian intens tentang kegiatan operasional yang dijalankan.

c. Dukungan dari pemberi waralaba, supaya meningkatkan kualitas

d. Pemasok bahan makanan atau minuman serta mesin atau peralatan yang membantu kegiatan operasional

e. Brand nama meliputi logo, slogan dan sebagainya

3. Manufacturing Plant Francising (Formula Produksi Barang) merupakan pemberian rahasia formula suatu produksi untuk dapat diproduksi dan didistribusikan sesuai standar yang dimiliki oleh pemberi waralaba. Seperti Coca Cola Production yang mempunyai rahasia formula pembuatan coca cola dan minuman ringanlainnya (Firdawati, 2011 : 42-43).

Dalam Islam, bisnis merupakan pekerjaan manusia yang dilaksanakan untuk memperoleh penghasilan sehingga mampu melaksanakan ibadah kepada Allah maupun kepada sesama manusia. Adapun prinsip-prinsip bisnis dalam Islam adalah:

1. Customer Oriented merupakan kepuasan seorang pelanggan terhadap produk serta manajemen yang diterapkan oleh sebuah perusahaan. Rasulullah SAW, dalam menerapkan prinsip bisnis selalu amanah dalam melaksankan perjanjian bisnis, jujur serta adil. Dampak yang diterapkan dari prinsip ini adalah para pelanggan tidak merasa dirugikan. Tidak ada masalah mengenai janji-janji yang telah disepakti diawal kontrak. Salah satu yang bisa diterapkan adalah dengan menunjukkan cacat barang yang diperjualbelikan kepada konsumen, dalam Islam hal tersebut disebut dengan bai' najasy yaitu memperlihatkan keadaan yang unggul atau baik kepada konsumen, padahal hal tersebut tidak sesuai dengan mutu dari suatu barang atau membohongi konsumen. Selain itu, dalam prinsip ini menerapkan hak khiyar (memperbolehkan konsumen untuk meneruskan atau 
membatalkan transaksi) jika terdapat penipuan dalam hal jualbeli.

2. Transparasi yaitu keterbukaan atau kejujuran mengenai komposisi, kuantitas dan mutu dari sebuah perusahaan agar tidak merugikan dan membahayakan pembeli. Prinsip transparasi merupakan kunci keberhasilan sebuah perusahaan. Prinsip ini juga harus mampu mengungkapkan bagaimana kondisi perusahaannya dalam keadaan baik atau tidak dan tidak menyembunyikannya. Transparasi berlaku pada laporan keuangan maupun laporan yang lainnya

3. Persaingan yang sehat. Dalam dunia bisnis Islam, anjuran untuk menghalalkan segala cara untuk memperoleh keuntungan tidak diperbolehkan. Akan tetapi didalam Islam tertera perintah tentang berlomba-lomba dalam kebaikan, yang bermaksud bahwa menerapkan strategi yang terbaik untuk usahanya sendiri, bukan untuk menghalalkan segara cara supaya pesaing yang lain bangkrut. Sebagaimana firman Allah dalam Surah AlBaqarah ayat 188 :

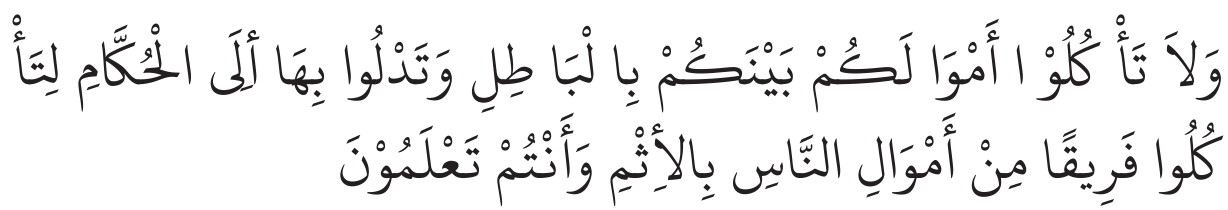

Dan janganlab kamu memakan harta sebahagian dari yang lain di antara kamu dengan jalan yang bathil dan (janganlab) kamu membawa (urusan) harta itu kepada hakim, supaya kamu dapat memakan sebahagian daripada harta benda orang lain itu dengan (jalan berbuat) dosa, padahal kamu Mengetahui.

Strategi yang diterapkan oleh Rasulullah ketika beliau menekuni dunia dagang adalah dengan jujur terhadap kondisi barang dagangan, memberikan pelayanan yang optimal dan melarang monopoli suatu barang kepada penjual karena hal tersebut adalah perbuatan dosa yang harus dihindari.

4. Fairness adalah keadilan. Prinsip keadilan yang diterapkan oleh Rasullullah adalah menerapkan sistem keadilan kepada semua stakeholder dunia bisnis untuk menjaga hubungan baik 
antara satu dengan yang lain. Keadilan kepada konsumen, dengan tidak merugikan konsumen melalui pernyataan bohong tentang kondisi barang, dan mengambil keuntungan dari suatu produk melebihi ketentuan yang sudah ditetapkan. Keadilan untuk karyawan adalah memberikan upah sesuai dengan kontrak diawal dan tidak mengeksploitasi hakhak pekerja. Keadilan berbisnis untuk pengutang adalah memberikan waktu tenggang kepada kreditor yang belum mampu membayar, karena rezeki itu merupakan ketetapan dari Allah swt. Bentuk keadilan berbisnis dalam Islam untuk produsen adalah menjauhi unsur riba karena menyebabkan eksploitasi dari yang kelebihan uang kepada yang kekurangan uang. Selain itu riba merupakan perkara yang sangat dibenci oleh Allah karena dapat merugikan sesama manusia.

Dalam Islam, konsep Bisnis waralaba merupakan pengembangan bentuk kerjasama (syirkah). Syirkah/Partnership merupakan hubungan antara 2 orang atau lebih untuk memperoleh laba/rugi yang dioperasionalkan oleh keseluruhannya atau salah satu sebagai pengelola yang lain (Muhammad, 2017 : 44). Franchisor menjalinn hubungan kerjasama dengan franchisee dengan waktu tertentu sesuai dengan perjanjian bersama untuk memperoleh keuangan. Kerjasama yang dilakukan dalam bentuk pemberian izin merek, format bisnis dan resep produksi.

Bisnis waralaba diperbolehkan dalam Islam jika memenuhi rukun dan syarat perjanjian. Syarat perjanjian menurut Islam adalah menjauhi segala bentuk riba, suka sama suka, prinsip keadilan, jujur, saling tolong menolong, dan memperhatikan kesejahteraan orang lain. Selain itu tujuan dari bisnis waralaba versi Islam (Muhammad, 2017 : 71) yaitu sebaga berikut :

1. Pemenuhan kebutuhan masyarakat

2. Persediaan terhadap kemungkinankemungkinan didepan

3. Pemenuhan sarana kegiatan sosial. 


\section{Metode Penelitian}

Penelitian ini menggunakna pendekatan kualitatif jenis fenomenologi. Dalam hal ini peneliti berupaya untuk mengungkap makna atau fenomena yang terjadi dalam suatu komunitas masyarakat di Kabupaten Probolinggo, terkait dengan branding "syari'ah" yang dilakukan oleh perusahaan bisnis waralaba, yaitu Kopontren Sidogiri, sebagai bagian dari adanya komodifikasi agama dalam sistem ekonomi tersebut. Tekhnik pengumpulan datanya dilakukan melalui indepth intreview,observasi, dokumentasi dan focus group discussion.

\section{Hasil Penelitian}

\section{Branding Syariah; Komodifikasi Agama dalam Bisnis Di Era Revolusi Industri 4.0}

Basmalah merupakan Kopotren (Koperasi Pondok Pesantren) Sidogori, yang sudah membuka cabang dibeberapa kota di provinsi Jawa Timur. PT Sidogiri Mitra Utama Basmalah berpusat di kota pasuruan, Jawa Timur. Kopotren Basmalah merupakan salah satu perusahaan ritel yang mulai meramaikan dunia persaingan bisnis ritel di Indonesia. Di Indonesia sendiri, keberadaan perusahaan ritel cukup banyak, seperti Indomaret, Alfamart, Alfa Midi, Circle $\mathrm{K}$ dan lain sebagianya. Perusahan ritel yang sudah berkembang merujuk kepada dunia barat dalam pengaplikasian semua operasional kerjanya. Perusahaan ritel yang berkiblat ke dunia barat, akan menerapkan sistem kapitalis dan ketentuan-ketentuan yang tidak sesuai dengan budaya di Indonesia, seperti menjual minuman beralkohol, banyak makanan atau minuman yang tidak halal atau menggunakan bahan baku dari minyak babi dan sebagainya. Kopotren Basmalah hadir memberikan udara segar kepada masyarakat wilayah Jawa Timur yang notabene beragama Islam, meredam rasa khawatir masyarakat tentang operasional yang dilaksanakan di perusahaan ritel lain yang tidak sesuai dengan kaidah Islam. Tahun 2013 Kopontren Sidogiri membentuk infrastruktur brand "BASMALAH" dengan nama "Kopontren Basmalah" dengan motto "Tempat Belanja yang Baik". 
Hasil penelitian menunjukkan bahwasanya persepsi masyarakat Kabupaten Probolinggo terhadap branding syariah yang diterapkan oleh Kopontren Basmalah sebagai berikut:

\section{Costumer Loyality Oriented}

Syariah branding pada Kopotren Basmalah mempunyai tujuan untuk menarik pelanggan dari berbagai lapisan masyarakat. Kopotren Basmalah yang berlabel agama Islam, mencoba membungkus kesan syariahnya dalam berbagai budaya-budaya yang Islami, hal tersebut terlihat dari penjaga Kopotren Basmalah yang menggunakan peci dan sarung. Pemakaian peci dan sarung identik dengan tingkat keshalehan seseorang. Kopotren Basmalah ingin melabelkan dirinya sebagai perusahaan ritel yang taat agama dengan menerapkan pemakaian peci dan sarung untuk menarik pelanggan di kawasan mayoritas muslim, padahal pada era revolusi industri 4.0 perkembangan fashion mengalami perubahan yang sangat dinamis.

Selain itu, untuk memberikan kesan syariahnya kepada pelanggan, Kopotren Basmalah memutar musik yang bergenre Islami yaitu lagu muratthal dan shalawatan. Pengoperasional musik tersebut ditujukan untuk mendatangkan keberkahan dari Allah SWT dan memberikan kenyamanan bagi pelanggan. Selanjutnya, atribut fisik yang disediakan oleh Kopotren Basmalah untuk mendatangkan pelanggan berupa lahan parkir yang luas, toilet yang bersih, susunan rak yang rapi dan bersih, suasana kopotren yang nyaman.

Kopotren Basmalah yang sudah berlabelkan Islam mampu menerapkan semua kegiatan operasionalnya sesuai dengan prinsip syariah, sehingga Kopotren Basmalah melakukan transakasi jual belinya ala Islam. Dalam Islam, akad jual beli terdiri dari 4 rukun yaitu, penjual, pembeli, barang, dan ijab qabul. Di perusahaan ritel lain, unsur keempat yaitu ijab qabul sangat jarang diterapkan, akan tetapi Kopotren Basmalah menerapkan perkataan "saya jual barang ini" dan pembeli menjawab "iya, saya beli barang ini" merupakan salah satu keunikan yang berbasis Islam. 
Perkembangan teknologi menuntut Kopotren Basmalah untuk menerapkan electronic money (e-money). E-money yang diterapkan pada Kopotren Basmalah adalah E-maal. E-maal adalah aplikasi yang diterapkan Kopotren Basmalah untuk mempermudah konsumen dalam kegiatan transaksi jual beli. Uang yang berfungsi sebagai alat tukar mampu digantikan dengan keberadaan e-maal.

Customer Loyality atau kepuasan pelanggan merupakan trik atau strategi Kopotren Basmalah untuk melariskan dagangannya. Kepuasan pelanggan adalah perasaan bahagia atau kecewa yang dialami oleh seorang pelanggan dengan membandingkan harapan dan kenyataan yang diperoleh, kepuasan pelanggan akan melahirkan ikatan emosional yang kuat terhadap merek atau perusahaan bersangkutan (Sembiring, 2014 : 3). Diffrensiasi yang diterapkan pada Kopotren Basmalah menjadi jargon dalam persaingan bisnis usaha. Hal-hal yang berbau syariah dikemas sedemikian rupa dalam kegiatan operasional untuk menciptakan hal yang unik dan dirasakana oleh konsumen.

Kepuasan pelanggan merupakan komitmen dan kesetiaan seorang pelanggan terhadap Kopotren Basmalah yang dapat diukur dengan kesetiaan seorang pelanggan melaksanakan pembelian sebanyak beberapa kali. Salah satu yang menjadi keunggulan Kopoten Basmalah adalah alumni dari Pondok Pesantren Sidogiri tersebar dibeberapa daerah Probolinggo. Alumni yang masih mempunyai rasa kepemilikan terhadap Kopotren Basmalah akan mengembangkan dan merekomendasikan Kopotren Basmalah kepada semua lapisan masyarakat Probolinggo (Dimyati, 2016 : 457).

\section{Performing Image}

Kopotren Basmalah yang didirikan oleh Pondok Pesantren Sidogiri mampu bertahan dan bersaing dengan perusahaan ritel lain. Pelaksanaan budaya dan adat istiadat yang sesuai dengan konsep akan menciptakan persepsi yang baik di mata masyarakat. Asumsi baik tentang Kopotren Basmalah terlihat dari banyaknya minat masyarakat untuk menjadikan kopotren sebagai tempat tujuan belanja untuk memenuhi kebutuhan sehari-hari. 
Antusiasme masyarakat terhadap Kopotren Basmalah dikarenakan beberapa pihak internal maupun eksternal yang terkait. Pihak internal, yaitu manajer dan seluruh karyawan yang merencanakan konsep yang dikemas dalam basis syariah tentang kegiatan operasional kopotren. Sedangkan faktor eksternal melalui alumni pondok pesantren sidogiri yang mempunyai ribuan alumni yang tersebar diseluruh Indonesia. Oleh karena itu, Kopotren Basmalah sudah mampu membuka beberapa cabang diberbagai kecamatan maupu desa di wilayah Probolinggo seperti kecamatan pakuniran, gading, kademangan, kraksaan, paiton dan sebagainya.

Kopotren Basmalah hadir sebagai salah satu aplikasi nyata dari Pesantren Sidogiri yang ingin menjudge sebuah pesantren mampu bersaing dalam dunia perekonomian. Pesantren Sidogiri memodifikasi ilmu agama dan ilmu ekonomi untuk melahirkan sebuah perusahaan ritel yang beratasnamakan syariah. Kopotren Basmalah menjadi acuan bagi pesantren lain yang ingin bergerak dalam bidang perekonomian. Kopotren Basmalah menjadi jargon perusahaan ritel yang berbasis syariah.

\section{Santri Entrepreneurship}

Asumsi masyarakat tentang kaum santri yang notabene ahli agama dan tidak cukup mahir di bidang bisnis, mampu ditepis dengan keberadaan Kopotren Basmalah.Kopotren Basmalah mampu bersaing dan tetap menancapkan tonggak kejayaannya ditengah perkembangan zaman. Kaum santri mampu menjadi ahli entrepreneurship dengan menerapkan semangat pengabdian pada masyarakat yang sudah diajarkan oleh para masayikh dan ulama. Etos belajar baik yang sudah diajarkan para guru secara tersurat maupun tersirat mampu diaplikasikan dalam dunia bisnis menjadi sebuah etos kerja.

Santri yang mempunyai pola hidup survive dalam berbagai keadaan dan mampu mengembangkan dirinya merupakan sebuah doktrin yang sudah tertanam serta menjadi filosofis kuat untuk menjalani kehidupan pasca di pesantren. Kaum santri dididik untuk tidak memberikan beban kepada orang lain, sehingga 
mampu menyelesaikan masalah dengan sendiri, termasuk untuk menyelesaikan permasalahan masa depannya dengan membuka lapangan pekerjaan bagi dirinya sendiri dan orang lain. Minat kaum santri tentang wirausaha cukup besar. Alasan seseorang berminat untuk berwirausaha yaitu sebagai berikut :

a. Alasan keuangan, yaitu untuk memenuhi kebutuhan keluarga, menambah pendapatan, menjadi kaya.

b. Alasan sosial, yaitu mampu dikenal oleh banyak orang dan menaikkan status dan gengsi keluarga.

c. Alasan pelayanan, yaitu untuk membuka lapangan kerja dan membantu perekonomian Indonesia.

d. Alasan pemenuhan diri, yaitu memenuhi kepuasan diri sendiri tentang bakat yang dimiliki, untuk menjadi manusia yang lebih mandiri, dan mampu memenuhi sesuatu yang diinginkan (Ulfa, $2015: 6$ ).

Konsep wirausaha merupakan keahlian dalam memodifikasikan sumber daya alam dan manusia untuk menciptakan sesuatu yang baru dan berbeda dengan berpikir kreatif dan inovatif untuk memperoleh keuntungan (Suryana \& Bayu, 2010 : 24). Begitu juga dengan minat berwirausaha santri pada Kopotren Basmalah. Etos kerja yang diterapkan pada santri di Kopotren Basmalah adalah nilai khidmad (pengabdian dan pelayanan) sebagai lahan menerapkan ilmu yang sudah diajarkan oleh para masayikh. Semangat khidmad yang diterapkan oleh para santri mampu mengembangkan Kopotren Basmalah membuka gerai minimarket di berbagai kecamatan di Kabupaten Probolinggo. Nilai khidmad yang diterapkan oleh santri di Kopotren Basmalah dengan mengutamakan kepentingan kopotren daripada kepentingan diri sendiri, menerapkan STAF yaitu Shiddiq (jujur), Tabligh (menyampaikan atau melayani konsumen), Amanah (dapat dipercaya) dan Fathonah (bekerja cerdas). Selain itu, penerapan nilai ilmu yang bermanfaat dengan cara menjadi pekerja yang baik dan produktif menjadi kekuatan tersendiri bagi santri di Kopotren Basmalah untuk mendapatkan keberkahan di dunia dan akhirat. 


\section{Ajang Keshalehan Sosial}

Kopotren Basmalah dijadikan salah satu wahana atau media untuk mengkategorikan bahwa dirinya "shaleh" secara sosial. Kopotren Basmalah menerapkan dan membungkus label Islam dengan berbagai budaya-budaya Islam yang diterapkan dalam Kopotren Basmalah sendiri. Branding Syariah pada Kopotren Basmalah menjadi sasaran empuk bagi masyarakat yang haus akan pengakuan sosial bahwa dirinya "shaleh". Masyarakat tersebut akan melaksanakan semua transaksinya pada Kopotren Basmalah.

Munculnya praktik keshalehan sosial merupakan trend baru yang sengaja diciptakan oleh kaum kelas menengah muslim. Keshalehan sosial merupakan ekspresi dan perilaku orang-orang Islam yang peduli dengan nilai-nilai sosial akan tetapi mengabaikan ibadah pribadinya. Kesalehan sosial merupakan upaya untuk menumbuhkan rasa cinta terhadap sesama dan berbela rasa terhadap orang yang membutuhkan (Nugroho, 2015 : 53).

Terdapat empat macam ritual keshalehan sosial yang menjadi indikator terhadap perubahan sikap seorang muslim yaitu 1) seberapa istiqomah untuk melaksanakan ibadah yang wajid dan sunah, 2) seberapa taat dan patuh menjalankan perintah berdasarkan Al-Qur'an dan Hadis, 3) seberapa tertarik dengan perayaan keagamaan, 4) hubungan nilai-nilai sosial ekonomi dengan nilai agama (Jati, $2015: 346$ ).

Pada indikator di atas, Kopotren Basmalah menduduki kategori keempat yaitu hubungan nilai-nilai sosial ekonomi dengan nilai agama. Kopotren Basmalah secara sengaja memilih konsep secara Islam untuk meningkatkan laju penjualan. Selain itu, maraknya tentang keshalehan sosial menjadikan Kopotren Basmalah sebagai lahan untuk mengakui bahwa dirinya shaleh secara sosial. Masyarakat yang memanfaatkan Kopoten Basmalah sebagai obyek untuk memenuhi kebutuhan sehar-hari, memiliki tujuan lain yaitu sebagai sarana rekreasi. 


\section{Perdebatan Keyakinan dan Jual Beli}

Agama hanya dijadikan alat atau wahana untuk pengakuan sosial, memperoyeksikan segala macam angannya tentang keshalehan sosial untuk memenuhi kebutuhan sosialnya. Ketika agama dijadikan kekuatan untuk mendongkrak nama besar suatu bisnis, bukanlah perkara yang dilarang dalam agama. Asumsi masyarakat tentang keberadaan Kopotren Basmalah yang menjual nama agama menjadi rupiah, bukanlah hal yang tidak diperbolehkan. Kopotren Basmalah memanfaatkan nama besar Islam menjadi suatu konsep untuk menciptakan differensiasi dan menarik pelanggan. Jadi, agama bukanlah barang yang mampu ditukarkan dengan rupiah. Agama merupakan nilai sakral yang tidak mampu dirubah sampai kapanpun.

\section{Kesimpulan}

Komodifikasi agama dalam bisnis merupakan salah satu pemanfaatan agama dalam mempopuleritaskan bisnis yang sedang dijalani. Agama merupakan ketentuan sakral dan suci yang tidak boleh dirusak oleh ilmu apapun. Sedangkan bisnis merupakan usaha yang dilakukan manusia untuk memenuhi kebutuhan dan keinginan jasmani dan rohani melalui kegiatan jual beli, tukar menukar serta tujuan memperoleh keuntungan.

Agama dan bisnis merupakan suatu ilmu dan keyakinan jika dipersandingkan akan melengkapi satu dengan yang lainnya. Pada kasus komodifikasi agama dalam bisnis ini, agama dijadikan wahana atau media atau alat untuk menjual produk dari bisnis tersebut. Hal itu merupakan strategi yang digunakan oleh pemilik perusahaan untuk meningkatkan laju penjualan. Dalam konteks agama, hal tersebut tidak menyalahi aturan agama, dikarenakan dalam agama sendiri, terdapat tugas manusia sebagai hamba yang pertama yaitu 'abd dan muamalah. 'Abd merupakan keyakinan seorang hamba terhadap Tuhannya atau komunikasi hamba terhadap Tuhannya. Sedangkan muamalah merupakan hubungan manusia dengan manusia yang lain. Kasus modifikasi agama dalam bisnis termasuk kategori muamalah yaitu hubungan manusia dengan manusia lain. 
Hal tersebut terlihat dari tujuan komodifikasi agama dalam bisnis adalah meningkatkan laju penjualan. 


\section{Daftar Pustaka}

Astuti, D. (2005). Kajian Bisnis Franchise Makanan di Indonesia. Jurnal Manejemen Dan Kewirausahaan, 7(1), 83-97.

Dimyati, M. (2016). Komparasi Pengaruh Relationship Marketing dengan Pengaruh Mediasi Kepuasan dalam Membangun Loyalitas Pasien Rumah Sakit Islam di Kabupaten Banyuwangi. Inferensi, Jurnal Penelitian Sosial Keagamaan, 1O(2), 451-472.

Fakhruroji, M. (2016). Komodifikasi Agama Sebagai Masalah Dakwah. Jurnal Ilmu Dakwah Vol., 5(16), 1-18. https://doi. org/10.15575/jid.v5i16.352

Farid, R. (2017). Kajian Strategi Branding Clothing Unkl347. Wimba, 8(1), 59-81.

Firdawati, L. (2011). Perjanjian Waralaba Menurut Hukum Islam. ASAS, 3(1), 40-49.

Ghufron, M. I. (2017). Konsep Maslahah Maximizer pada Hotel Syariah Perspektif Etika Bisnis Islam. Jurnal Islam Nusantara, 1(2), 131-143.

Harto, K. (2018). Tantangan dosen ptki di era industri 4.0. Jurnal Tatsqif, Jurnal Pemikiran Dan Penelitian Pendidikan, 16(1), 1-15.

Hidayat, A., Sujana, A., \& Al Gadri, H. H. (2018). Representasi Sosial Komunitas Pesantren Tentang Makna Kedamaian. Inferensi, Jurnal Penelitian Sosial Keagamaan, 12(1), 107-126.

Husna, A. (2018). Komodifikasi Agama: Pergeseran Praktik Bisnis dan Kemunculan Kelas Menengah Muslim. Jurnal Komunikasi Global, 2(2), 227-239.

Jati, W. R. (2015). Kesalehan sosial sebagai ritual kelas menengah muslim. Jurnal Kebudayaan Islam, 13(2), 336-348.

Marzali, A. (2012). Agama dan Kebudayaan. UMBARA, 1(1), 57-75. Muhammad. (2017). Manejemen Keuangan Syariah. Yogyakarta: UPM STIM YKPN. 
Muslim, M. B. (2012). Perbandingan Ekonomi Islam dan Ekonomi Kapitalis. Al-Iqtishad, IV(2), 305-320.

Nasrullah, M. (2015). Islamic Branding, Religiusitas Dan Keputusan Konsumen Terhadap Produk. Jurnal Hukum Islam (JHI), 13(79), 79-87. https://doi.org/10.1017/ CBO9781107415324.004

Nugroho, W. (2015). Keterlibatan Sosial sebagai Sebuah Devosi Sebuah Kesalehan Sosial Tarekat Naqsbandiyah Nazimmiyah. GEMA TEOLOGI, 39(1), 33-56.

Nurohman, Y. A. (2017). Theoritical Review : Teori Merek Halal. Among Makarti, 10(20), 85-94.

Prasetyo, H., \& Sutopo, W. (2018). Industri 4.0: telaah klasifikasi aspek dan arah perkembangan riset. J@ati Undip: Jurnal Teknik Industri, 13(1), 17-26.

Roziqin, Z., \& Rozaq, H. (2018). Menggagas Competitive Advantage melalui Branding Image. Jurnal Ilmiah DIDAKTIKA, 18(2), 225-244.

Rusli, T. (2015). Analisis terhadap Perjanjian Waralaba (Franchise) Usaha Toko Alfa Mart. Keadilan Progresif, 6(1), 64-75.

Satya, V. E. (2018). Strategi Indonesia Menghadapi Industri 4.0. Puslit BKD, X(9), 19-24.

Sembiring, I. J. (2014). Pengaruh Kualitas Produk dan Kualitas Pelayanan terhadap Kepuasan Pelanggan dalam Membentuk Loyalitas Pelanggan (Studi pada Pelanggan McDonald's MT.Haryono Malang). Jurnal Administrasi Bisnis, 15(1), 1-10.

Suryana, Y., \& Bayu, K. Kewirausahaan Pendekatan Karakteristik Wirausahawan Sukses (2010). Jakarta: Prenadamedia

Susanti, D., \& Rochman, K. L. (2016). Analisis Terhadap Komodifikasi Tubuh Perempuan dalam Iklan Es Krim Magnum versi Pink \& Black. KOMUNIKA, 1O(2), 201-218.

Susanti, J. (2016). Pengelolaan Keuangan Lembaga Syariah (1st ed.). Malang: Empat Dua. 
Toha, I. A. hafidz M. (2014). Panca Keilmuan Kado dari Pesantren untuk Masyarakat. Paiton: Ma'had Nurul Jadid.

Ulfa, N. (2015). Minat Wirausaha Kaum Santri dan Faktor-Faktor yang Mempengaruhinya (Studi pada Pondok Pesantren ArRiyadh Palembang). I-Economics Jurnal, 1(1), 1-34.

Yusuf, M. F. (2016). Komodifikasi : Cermin Retak Agama di Televisi: Perspektif Ekonomi Politik Media. Inject: Interdiscipliny Journal of Communication, 1(1), 25-42.

Zaenurrosyid, A., \& Ulfiana, L. Z. (2016). Komodifikasi Agama dalam Islamic Tourism dan Aktivitas Ekonomi. Jurnal Islamic Review, V(1), 109-123.

Zaroni, A. N. (1992). Bisnis dalam Perspektif Islam (Telaah Aspek Keagamaan dalam Kehidupan Ekonomi). MAZAHIB, $I V(2)$, 172-184. 